\title{
Republican themes in the Irish constitutional tradition
}

\section{Eoin Daly}

\section{Q OpenEdition \\ 1 Journals}

\section{Electronic version}

URL: http://journals.openedition.org/etudesirlandaises/5047

DOI: 10.4000/etudesirlandaises.5047

ISSN: 2259-8863

\section{Publisher}

Presses universitaires de Rennes

\section{Printed version}

Date of publication: 30 November 2016

Number of pages: 163-184

ISBN: 978-2-7535-5358-3

ISSN: 0183-973X

\section{Electronic reference}

Eoin Daly, "Republican themes in the Irish constitutional tradition », Études irlandaises [Online], 41-2 | 2016, Online since 30 November 2018, connection on 19 April 2019. URL : http:// journals.openedition.org/etudesirlandaises/5047 ; DOI : 10.4000/etudesirlandaises.5047 


\title{
Republican Themes in the Irish Constitutional Tradition
}

\author{
Eoin DALY \\ National University of Ireland Galway
}

Abstract

Ostensibly, the Irish Constitution of 1937 draws philosophical inspiration from Catholic social teachings and the theory of natural law. While it enshrines rather generic concepts of democracy and popular sovereignty, it seems bereft of distinctively republican ideas, despite the republican influences of the Irish political revolution. However, this article argues that many of the central devices and institutions of the Constitution may be interpreted in a republican light.

Keywords: constitution, republicanism, sovereignty, rights.

\section{Résumé}

La Constitution irlandaise de 1937 sinspire ostensiblement de l'enseignement social de l'Eglise catholique et de la théorie du droit naturel. Bien qu'elle consacre des principes généraux relativement banals en termes de démocratie et de souveraineté populaire, elle ne semble pas avoir un caractère typiquement républicain, malgré les inspirations républicaines de la révolution politique irlandaise. Toutefois, cet article affirme qu'un certain nombre de dispositifs institutionnels centraux de la Constitution peuvent être interprétés dans une perspective républicaine.

Mots clés : constitution, républicanisme, souveraineté, droits.

\section{圈 Introduction}

The approaching centenary of the Irish state has, unsurprisingly, prompted a great deal of reflection as to its republican character and credentials, and particularly as to the legacy of the republican ideas and rhetoric that motivated much of the political revolution from which the independent polity emerged. Much of this analysis has focused on the political culture of the State, and particularly its alleged pathologies of clientelism and corruption. However, relatively little has been said about the republican character, or otherwise, of the Irish Constitution. On the one hand, the Constitution of 1937 was seemingly influenced by Catholic social thought and characterised by a bellicose Gaelic-Christian nationalism that seemed 
rather bereft of republican potential. On the other hand, there are clear imprints of traditional republican ideas in constitutional provisions and principles relating to the structure and ethos of state institutions - some of which differentiated the new state from the parliamentary-centred model of the British constitution.

Accordingly, in this article I will consider to what extent republican ideas have influenced the Irish Constitution both in its historical and contemporary form. On the one hand, I will argue that the Constitution embraces many rather generic, non-specific republican ideas - like the rule of law, equality before the law and even the separation of church and state - that seem unremarkable with reference to the wider landscape of European liberal democracies. Equally, more distinctively "republican" concepts - such as civic participation and civic virtue are either conspicuously absent or at least muted in the wider landscape of Irish constitutional thought. However, I will also argue that many of the central devices and institutions of the Irish Constitution may be interpreted in a specifically republican light.

I will make this argument with reference to two particular areas of constitutional doctrine: popular sovereignty and constitutional rights. I will argue that while the ideology of popular sovereignty seems to enshrine a plebiscitary concept of democracy that keeps the people at "arm's length" in constituted governance, it can equally be understood as a means of checking executive dominance in the area of constitutional change, and ultimately as a safeguard against arbitrary governance. Similarly, while the acceptance of judicial supremacy in relation to constitutional rights seems to stem from an American-influenced liberalism - one that has a depoliticizing and decidedly unrepublican character - equally rights can be interpreted not simply as a guarantee of non-interference for individuals against the state, but rather as safeguards to ensure the primacy of the common good in the context of legislative process. Thus, my argument neither assumes any authentic, true version of the republican tradition, nor does it claim the Constitution itself has a singular or even a distinctive ideological or philosophical character. Rather the argument is a more modest one: it is that while the existing, amorphous precepts of constitutional doctrine have most often been understood in relation to liberal or communitarian ways of thinking, they are amenable to being reinterpreted in light of distinctively republican values.

In the first section, I will discuss the transposition of republican themes in different constitutional traditions, and give a brief assessment of their applications in the Irish context. In the second and third sections, I will consider how two of the central doctrines of the Irish Constitution - popular sovereignty and "natural" individual rights - may be reconceptualised in a distinctively republican sense. 


\section{Republican constitutionalism: an overview}

While the republican tradition is usually defined with reference to the ideals of civic virtue, participative self-government and freedom as non-domination, its specific forms and instantiations are diverse and its conceptual and philosophical parameters are deeply contested. Indeed, it is sometimes argued that the republican tradition simply has no conceptual or philosophical unity across different historical and nationally specific instantiations ${ }^{1}$. Republicans have sometimes understood citizenship in a full-throated, ancient sense as the highest realisation of the good life, but also in a more instrumental sense as a means of protecting individual liberties and private property ${ }^{2}$. Republicanism has been associated with austere, martial social mores, but has equally taken root in liberal, commercial societies. Besides, it is not self-evident why republicanism should be considered an attractive framework for contemporary politics: historically, as Goodin points out, republican ideas have carried a price in terms of personal autonomy, cultural pluralism and even toleration ${ }^{3}$, while real-life republican societies have engendered various forms of "communitarian excess".

Correspondingly, republican idealism has received startlingly different constitutional expressions. For example, while figures like Jean-Jacques Rousseau advocated a "direct" model of participative democracy, republicans like James Madison argued for a highly mediated and representative form of politics, with both appealing to the overarching ideals of civic virtue and non-arbitrary government. Modern republicanism is associated with the unitary and indivisible state advocated by Rousseau, but also the federalism or "checks and balances" expounded by Madison". Similarly, both the model of parliamentary supremacy that defines British public law, and the contrasting vision of judicial supremacy that has prevailed for two centuries in the United States, have been interpreted and defended in "republican" terms $s^{6}$. To an extent, this reflects reasonable disagreement concerning how abstract ideals such as non-domination or non-arbitrary rule may be institutionally instantiated. However, it also simply reflects the extraordinary malleability of the republican ideal in politics generally, and the fact that it is flexible

1. Robert Goodin, "Folie Républicaine”, Annual Review of Political Science, Vol 6, nº 1, June 2003.

2. See generally Iseult Honohan, Civic Republicanism, London, Taylor \& Francis, 2002.

3. Ibid. Kautz also argues that republicanism breeds intolerance. See Steven Kautz, "The Liberal Idea of Toleration", American Journal of Political Science, Vol. 37, n², May 1993.

4. Goodin, "Folie Républicaine". In Honohan's terms, the classical version of republicanism has been decried as "inherently oppressive, moralistic, exclusive, militarist and masculinist'. Honohan, Civic Republicanism, p. 6.

5. Honohan, Civic Republicanism, op. cit., Chapter II.

6. See especially Richard Bellamy, Political Constitutionalism, Cambridge, Cambridge University Press, 2007; Adam Tomkins, Our Republican Constitution, Oxford, Hart, 2005; see Tomkins, Our Republican Constitution, op. cit. 
(or indeterminate) enough to have been invoked in support of opposing political visions, both populist and elitist, radical and conservative.

Nonetheless, certain common themes emerge in the historical and contemporary expressions of republican constitutionalism. On the one hand, republican thinkers have historically understood freedom not as the absence of interference or coercion as such, but rather as security against arbitrary power ${ }^{7}$. In Philip Pettit's interpretation of the Roman and renaissance republican tradition, "the antonym of freedom [is] not interference but rather domination - exposure to the arbitrary, uncheckable power of a dominus or a master in one's life ${ }^{8}$ ". In turn, constitutional scholars like Bellamy and Tomkins have argued that this republican concept of freedom is given expression, at the political level, in the parliamentary model of accountable government. Thus, political freedom, in its republican sense, is not realised through any definite set of individual rights, placed above and beyond politics - but rather through a political structure that enshrines the equal status of citizens who are deeply divided as to questions of "right", as well as the good. In one strand of the republican constitutional tradition, then, there is strong resistance towards any attempt to juridify or depoliticise "rights".

Ostensibly, the contrasting American model of constitutionalism, predicated on judicial supremacy in relation to controversies around rights, appears more remote from historical republican thinking - simply because it seems to depoliticise rights, and privileges negative individual freedom as an overarching normative goal. That is, it seems to conceive of freedom simply as a constraint on government power, and of "rights" as being put beyond the ordinary fray of political contestation, in the sense that liberal philosophers like Dworkin and Rawls defend ${ }^{9}$. In this framework, citizenship and political participation are assigned a more modest and instrumental value. Yet this liberal model of constitutionalism can equally claim the republican mantle. Judicially enforced constitutional rights may be interpreted not simply as purely negative liberties or as barriers against state power, but rather as safeguards against arbitrary government, and as checks on the predicates of state power rather than as objective moral rights per $\mathrm{se}^{10}$. Indeed, Pettit himself rejects the idea that republicanism should be constitutionally translated as a model of parliamentary supremacy: he embraces a version of "legal constitutionalism" in order to promote broad

7. See generally Quentin Skinner, Liberty before Liberalism, Cambridge, Cambridge University Press, 1998.

8. Philip Pettit, "The Tree of Liberty: Republicanism, American, French and Irish", Field Day Review, vol. 1, no 1, 2005, p. 30.

9. John Rawls, Political Liberalism, New York, Columbia University Press, 1996; Ronald Dworkin, Taking Rights Seriously, London, Duckworth, 1978.

10. Richard Pildes, "Why Rights Are Not Trumps: Social Meanings, Expressive Harms, and Constitutionalism' The Journal of Legal Studies, Vol. 27, , nº 2, June 1998. 
contestation and "checks and balances" as the best institutional expression of the Roman-republican ideal ${ }^{11}$.

These themes have found a relatively muted expression in the Irish constitutional tradition. Of course, republicanism itself has, in Ireland, been strongly associated with extra-constitutionalist and violent versions of nationalism. Garvin has described Irish republicanism as "nationalist, separatist, vaguely socialist and sometimes Caesaro-papist ${ }^{12}$ ". And with the campaign of the Provisional IRA in the context of the Northern Irish Troubles, republicanism in recent decades became associated with ethno-religious nationalism, in contrast with the older anti-sectarian thinking associated with the United Irish movement ${ }^{13}$. Indeed a pessimist might conclude that there is little scope for a vibrant republican culture in a policy where civic morality was historically divested to the religious domain - or more recently, identified with the demands of the market ${ }^{14}$. And indeed, for obvious reasons, constitutional debates in the early independent state tended equally to focus on the external dimensions of sovereignty rather than on domestic political structures ${ }^{15}$. While the American constitutional tradition draws on Madison's republicanism and its French counterpart more from Rousseau, there is no equivalent or distinctive inspiration in the Irish constitutional context.

However, Irish republican discourse has not been completely severed from wider republican thinking. While historical Irish-republican thought was more concerned with freedom from external domination than with internal constitutional arrangements, O'Callaghan has argued that its nationalist rhetoric was infused with and borrowed from the classical and the $18^{\text {th }}$-century republican traditions ${ }^{16}$. Indeed there are strong traces of republican thinking in nationalist rhetoric: the 1919 Declaration of Independence affirmed: "The Irish people is resolved to secure and maintain its complete independence in order to promote the common weal ${ }^{17}$." De Valera's romantic vision of austerity and rural virtue might seem a departure from bona fide republican thought, yet in fact it echoes some of its his-

11. Philip Pettit, On the People's Terms: a Republican Theory and Model of Democracy, Cambridge, Cambridge University Press, 2013.

12. Tom Garvin, "An Irish republican tradition", Iseult Honohan (ed.), Republicanism in Ireland: Confronting Theories and Traditions, Manchester, Manchester University Press, 2008, p. 23-30, p. 24.

13. Kevin Whelan, "Republicanism: The Legacy of the United Irishmen", in Robert Savage (ed.), Ireland in the New Century, Dublin, Four Courts Press, 2003.

14. See e.g. Fintan. O'Toole (ed.), Up the Republic! Towards a New Ireland, London, Faber and Faber, 2012.

15. Admittedly, there were some attempts at democratic experimentation in the Irish Free State. See Laura Cahillane, 'Anti-Party Politics in the Irish Free State Constitution', Dublin University Law Journal, vol. 35, $\mathrm{n}^{\circ}$ 1, May 2012, p. 34-71.

16. Margaret O'Callaghan, "Reconsidering the Republican tradition in nineteenth-century Ireland”, in Honohan (ed.), Republicanism in Ireland, op. cit., p. 31-44.

17. Dáil Éireann Debates, op. cit., Volume 1, 21 January 1919. 
torical strands: Rousseau, indeed, celebrated peasant autarky as a social framework for republican virtue ${ }^{18}$.

Furthermore, while the "republican" identity of the State was muted in the context of the Northern Ireland conflict, the concept has arguably been rehabilitated or "reclaimed" in recent years ${ }^{19}$. Increasingly, the idea is invoked not only in the narrow terms of sovereignty and national self-government, but also in relation to broader themes of citizenship across social and economic life. In the discourses of President Michael D. Higgins as well as other public figures, the idea of the Republic has, for example, been invoked against clerical interference in politics, political corruption, and socio-economic inequalities ${ }^{20}$. And to an extent at least, these republican themes of civic virtue and the common good seemed to have particular resonance during a social and economic crisis that stemmed from the deregulatory excesses and governmental failures of the Celtic Tiger era ${ }^{21}$. Many of the major political parties have laid claim to the republican mantle, to the extent that, far from representing a violent fringe, the phrase risks becoming empty and banal. Indeed, perhaps it can be argued that "republican" thinking, in Ireland as elsewhere, lacks specificity and has become a synonym for all that is wholesome in politics.

Nonetheless, this revived interest in republican thinking invites a reappraisal of the republican influences in the historical and contemporary forms of Irish constitutionalism. Ostensibly at least, the Irish Constitution does not seem to draw its inspiration from distinctively republican thought; rather it appeals both to "natural" rights - this being partly a product of religious influence - as well as appealing to a national identity that is defined in Gaelic and Christian, rather than purely civic terms, as seems evident in the preamble in particular, with its invocation of "our Divine Lord, Jesus Christ", as well as the "centuries of trial" attributed to ancestral heroes ${ }^{22}$. While it gives a central position to ideals of popular sovereignty and democracy, these are quite generic and non-specific concepts that are not especially associated with republican thought, and indeed which may seem quite hollow when considered in light of the practical realities of the State to which the Constitution refers. Similarly, a concept of rights as "natural" rather than distinctively civic or political constructs - that is, as being above or beyond politics - seems inconsistent with republican thinking on the subject of individual rights. However, in the following sections I will argue that while distinctively republican ideas are not particularly prominent in the constitu-

18. See e.g. Jean-Jacques Rousseau, Projet de Constitution pour la Corse, Paris, Nautilus, 2000.

19. See e.g. Honohan, Republicanism in Ireland, op. cit.

20. See in particular Michael D. Higgins, Renewing the Republic, Dublin, Liberties Press, 2012.

21. See generally O'Toole, Up the Republic!, op. cit.

22. See preamble, Constitution of 1937. 
tional text, and while the Constitution has not been interpreted or instantiated in a particularly "republican" way, the central devices and institutions of the Constitution can nonetheless be re-conceptualised in a distinctively republican light.

\section{Popular sovereignty}

Popular sovereignty has been understood as the definitive and overarching principle of the Irish constitutional order. Article 6 proclaims that all "powers of Government" are derived - albeit "under God" - from "the people". In more practical terms, the idea of popular sovereignty served as a legitimating principle for the enactment of the Constitution in the post-independence context as well as something approximating a constitutional doctrine that differentiated the new state from the British constitutional tradition.

To an extent, the principle of popular sovereignty served as the philosophical foundation stone of the Constitution, which differentiated it from the parliamentary-focused British tradition. The emphasis on popular sovereignty in both 1922 and 1937 Constitutions "represented a decisive break with the British constitutional tradition, which viewed sovereign authority as vested in the political organs of the State rather than in the people as such ${ }^{23}$ ". O'Cinneide notes an early "desire to give substantive effect to the idea of popular sovereignty [which] led the drafters of both constitutions to experiment with different methods of ensuring greater popular participation ${ }^{24}$ ". While the 1922 Constitution was viewed by republicans as offering a limited and compromised form of national sovereignty, the enactment of a new Constitution through a national plebiscite partly served to put beyond doubt that the State derived from the constituent Irish "people" rather than the consent or acquiescence of the Westminster Parliament. Popular sovereignty both legitimated and defined the new Constitution, with de Valera asserting in the Dáil debates that the new charter made the people the "masters ${ }^{25}$ ".

The invocation of popular sovereignty also reflected the contemporary realpolitik. It proved politically expedient in the peculiar historical circumstances in which the current Constitution of 1937 emerged: the enactment of the Bunreacht broke the chain of legal continuity with the Irish Free State Constitution and the Anglo-Irish Treaty, which made no provision for the possibility of a new constitution being enacted. And so de Valera appealed directly to the "people" as an ultimate and overriding source of legitimacy for the new Constitution ${ }^{26}$. The

23. Colm O'Cinneide “The People are the Masters: the Paradox of Constitutionalism and the Uncertain Status of Popular Sovereignty within the Irish Constitutional Order", Irish Jurist, vol. 48, n 1, May 2012, p. 251.

24. O'Cinneide, "The People are the Masters", op. cit., p. 273.

25. See Dáil Éireann debates, Volume 67, op. cit., Col 74-76, 11 May 1937.

26. "The people... can effect this revolution". See ibid. 
plebiscite of 1937 - a constituent moment - allowed the authority of the new Constitution to be grounded in new, extra-legal source - the consent and affirmation of the voting "people". De Valera understood the plebiscite as a mechanism through which the people could re-assert its original sovereignty and thereby override the legal constraints of the constituted order. He appealed to the authority of "the sovereign people who are above the lawyers and above the Government and all others". The new constitution, he said, would be "the foundation law of the sovereign people of this country ${ }^{27 "}$.

Therefore, from the outset, popular sovereignty was associated with the expression of the popular voice in referendum exercises. One of the distinctive, and unusual, features of the Constitution was the fact that it could only be amended through a referendum process. In turn, this has been understood as the primary, if not the exclusive mechanism for giving expression to popular sovereignty.

The understanding of the Irish people as "sovereign" oscillates between enshrining a purely symbolic status for the people as the constituent power and the nominal source of political authority, and actually according the people a direct role in the governance of the state. Indeed the concept of "sovereignty" is used in ambiguous and sometimes contradictory ways in legal and political theory. In some instances it refers to the supreme governing agent within a polity, as in Hobbes' or Austin's account - as the uncommanded commander $^{28}$. But in contemporary democratic societies, it is typically used to designate the "people" not as an active governing agent, but rather as the source of governmental authority in a more formal and symbolic sense, or as an authorising agent rather than an actively governing one ${ }^{29}$.

In the Irish constitutional case law, the principle has been invoked almost exclusively in relation to the people's role in the constitutional-amendment process. On the one hand, the device of the constitutional referendum is commonly taken as a hallmark and expression of popular sovereignty. On the other, popular sovereignty has been interpreted, in practical terms, as meaning that the people's right of constitutional amendment is substantively unfettered. Unusually in European terms, this means that no constitutional principle is unamendable or immutable $e^{30}$. Indeed the concept of popular sovereignty has almost been conflated with the referendum mechanism. The Supreme Court, for example, noted,

27. Ibid.

28. Thomas Hobbes, Leviathan: Or the Matter, Forme, and Power of a Common-Wealth Ecclesiasticall and Civill, ed. by Ian Shapiro, Yale, Yale University Press, 2010; John Austin, The Province of Jurisprudence Determined, London, John Murray, 1832.

29. For this distinction see Peter Steinberger, "Hobbes, Rousseau and the Modern Conception of the State", The Journal of Politics, 70: 595, 2008.

30. As Casey notes, "other western European constitutions characteristically declare one or more matters immutable." James Casey, Constitutional Law in Ireland, Dublin, Round Hall Sweet \& Maxwell, 2000, p. 709. 
"the Constitution... was enacted by the people and... can be amended by the people only [as] the sovereign authority ${ }^{31}$ ". Popular sovereignty has consistently been invoked to reject various challenges to constitutional amendments that were alleged to have violated supposedly immutable or essential constitutional principles, particularly the principles of natural law ${ }^{32}$ ". Thus the Supreme Court has rejected the argument that even "natural" human rights in the Constitution are immutable or unamendable, reasoning that "the people intended to give themselves full power to amend any provision of the Constitution 33 ". Thus "a propo-

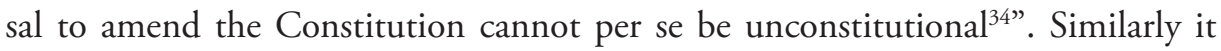
has been said "there can be no question of a constitutional amendment properly before the people and approved by them being itself unconstitutional ${ }^{35 "}$. And this view of referendums as expressions of sovereignty has been reflected, to an extent, in wider constitutional theory as well as in jurisprudence: Tierney, for example, suggests that constitutional referendums potentially represent "true conduits of popular determination ${ }^{36 "}$.

However, this has led to certain conceptual tensions in relation to the substance and scope of popular sovereignty. Unusually, the normative identity of the Irish Constitution has not been associated with any of its substantive principles, but rather its method of adoption and amendment. Relatedly, popular sovereignty itself is understood simply in procedural rather than substantive terms. It has not been identified with any specific rights or principles - for example, the rights citizens might need to meaningfully participate in government. Rather, it has been understood reductively in relation to the people's formal role in the constituent process. Put simply, popular sovereignty translates to a procedure for determining constitutional content, and not to any definite content. If popular sovereignty is understood in purely procedural terms, this is potentially selfcontradicting if the substance or content of popular rule is undermined through the constitutional-amendment process. Thus the procedural aspect of popular sovereignty is arguably self-limiting. Arguably it could not, for example, logically be used to remove or undermine the preconditions for the exercise of popular sovereignty itself - particularly the rights of expression, association and suffrage which are needed to participate in the political process. Philip Pettit, for example, argues that rights relating to democratic contestation must be placed beyond the

31. Byrne v Ireland [1972] IR 241, 262, emphasis added.

32. Finn v Att. Gen [1983] IR 154; Riordan v An Taoiseach (No.1), [1999] 4 IR 321.

33. Finn v Att. Gen [1983] IR 154, 163, emphasis added.

34. Slattery $v$ An Taoiseach [1993] 1 IR 286.

35. Riordan v An Taoiseach (No.1), [1999] 4 IR 321, 330.

36. Stephen Tierney, "Constitutional referendums: a theoretical inquiry", Modern Law Review, vol. 72, $\mathrm{n}^{\circ} 3$, September 2009, p. 364, emphasis added. 
constitutional amendment process. ${ }^{37}$ The Constitution, he argues, must "put various issues off the popular agenda ${ }^{38}$ ".

As discussed, the Supreme Court has affirmed that: "the Constitution... is the fundamental and supreme law of the State representing... the will of the People ${ }^{39}$. Correspondingly it has been assumed that interpreting the Constitution is essentially an exercise in retrieving the will of the people as expressed in the referendum process ${ }^{40}$. In Tierney's terms, this is the view that the constitutional referendum allows the people to "produce' sovereign decisions ${ }^{41}$ ", such that ultimately the Constitution embodies "the settled will of a democratic people ${ }^{42}$ ".

However, this overstates the degree of agency the people enjoys in the context of the constitutional-amendment process. Somewhat ambitiously, it presumes both that the referendum is capable of crystallising a collective "will" - on the part of a unitary corporate entity called "the people" - and in turn that the constitutional text can effectuate this will. The idea that the constitutional referendum inscribes the popular will in the basic law of the state not only makes dubious assumptions concerning group agency and the possibility of collective will ${ }^{43}-$ more simply, it ignores the various ways in which popular agency is checked and contained by various elite-driven processes. Of course, constitutional referendums cannot be initiated spontaneously by the "people" themselves, not least because the initiative mechanism is reserved formally speaking to the Oireachtas, and in effect, to the Government. Thus while constitutional jurisprudence often speaks as if the people enjoyed an unconditioned, freestanding power of amendment, in effect they only enjoy a veto power in a multi-stage constitutional-amendment process. The people's agency is constrained by various intermediary institutions ${ }^{44 ”}$.

Thus, the people's power is far more modest than what constitutional mythology suggests. In political-theory terms, the constitutional referendum mechanism affords the people (limited) influence, but not control of the kind that "sovereignty" implies. Being couched within a limiting initiative procedure, the people can never be seen as engaged in a freestanding act of creation or control. In the context of the amendment process, the people are very much a constituted,

37. See Pettit, On the People's Terms, op. cit., Chapter 4. Pettit suggests: "This is not to put a brake on democracy but to ensure people have truly equal access to democratic influence"; p. 207.

38. Ibid.

39. Re Article 26 and the Regulation of Information (Services Outside the State for Termination of Pregnancies) Bill 1995 [1995] 1 IR 1.

40. In Sullivan v Robinson, Justice O’Byrne suggested "a Constitution is to be liberally construed so as to carry into effect the intentions of the people embodied therein." [1954] IR 161, 174.

41. Tierney, "Constitutional referendums: a theoretical inquiry", p. 363.

42. Ibid., p. 366.

43. See generally Jane Schacter, "The Pursuit of 'Popular Intent': Interpretive Dilemmas in Direct Democracy”, Yale Law Journal, vol. 105, n 1, 1995. Also see Honohan, Civic Republicanism, p. 220, emphasis added.

44. See Eoin Daly, "A republican defence of the constitutional referendum", Legal Studies, vol. 35, nº 1, 2015. 
rather than a constituent authority, as part of an interaction of different mutually constraining assemblies and authorities and with a procedurally couched role.

Moreover, there has been little sustained effort to relate this foundational political principle of the Constitution to more substantive themes of citizenship and civic participation. As O'Cinneide has argued, de Valera's assertion that the Constitution made the people the "masters" rings hollow given that, for most practical purposes, the "people" are kept "at arm's length" in the constituted governance of the State ${ }^{45}$. Indeed the State established a marked contradiction between an emphatic official emphasis on popular sovereignty as a definitive constitutional doctrine, and the marginalisation of the abstract, sacralised "people" in the actual business of government ${ }^{46}$ ". Tentative democratic experimentation - such as the popular initiative procedure originally envisaged in the Constitution of 1922 waned in the fraught political environment of the 1920s and $1930 \mathrm{~s}^{47}$.

Thus it has been commonplace for constitutional theory and jurisprudence to invoke "the people" as the formal source of constitutional authority almost as an empty formula - as a purely abstract proposition that fails to consider citizenship in concrete, participative terms. It has been argued that popular sovereignty occupies a "quasi-religious" position in constitutional jurisprudence ${ }^{48}$ - that it is "venerated in constitutional theology" ${ }^{49}$ ". But this simply is not reflected in the realities of the independent state, and, in particular, the "sharp disconnect in Ireland between the people and the systems of governance by which they are ruled $^{50 "}$.

Nonetheless, the plebiscitary characteristics of the Irish Constitution, and the accompanying rhetoric of popular sovereignty, can be re-interpreted in distinctly republican terms.

Of course, the idea that constitutional referendums give the sovereign people "direct control ${ }^{51}$ " over constitutional content is simply unrealistic, for the reasons outlined. Indeed, republicans have historically been sceptical towards "direct" or purely majoritarian democracy, fearing the spectre of majority domination or tyranny. For Pettit, it risks engendering "the ultimate form of arbitrariness, the tyranny of a majority ${ }^{52 "}$. James Madison described "pure" democracy as "incompatible with personal security or the rights of property ${ }^{53}$ ". Instead republicans

45. Colm O’Cinneide, “The People are the Masters”, p. 256.

46. Ibid.

47. Ibid., p. 274.

48. Gary Jacobsohn, Constitutional Identity, Harvard, Harvard University Press, 2010.

49. O’Cinneide, "The People are the Masters", art. cit., p. 256.

50. Ibid., p. 252.

51. Stephen Tierney, Constitutional Referendums: The Theory and Practice of Republican Deliberation, Oxford, Oxford University Press, 2012, p. 13, 15.

52. Philip Pettit, Republicanism: A Theory of Freedom and Government, Oxford, Clarendon Press, 1997, p. 8.

53. James Madison, Federalist no. 10, New York, Clinton Rossiter, 1961, p. 81. 
have advocated a model of "checks and balances' or mutually constraining assem-

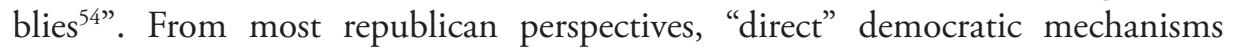
undermine the moderating virtues associated with parliamentary democracy. Indeed, Pettit, for example, contrasts the neo-Roman tradition with Rousseau's "communitarian" conception of political freedom, which, he argues, requires citizens to deliberate upon and directly legislate the "general will, the corporate will of the political community 55 ". Thus, republicans are likely to be apprehensive of constitutional referendums, where they are presented as exercises in popular sovereignty that override and sidestep the equilibrium of constituted authorities and assemblies. They will fear that direct-democracy exercises undermine the moderating and deliberative virtues of political representation, exalting "brute preference" above "the good of the group ${ }^{56 "}$. Indeed, Pettit apprehensively describes "a plebiscitarian dispensation in which each participant privately forms his or her judgment about common avowable interests, rather than doing so in dialogue with others ${ }^{57 "}$.

However, I argued in the previous section that the constitutional referendum cannot coherently be understood as a pure or unbridled expression of popular will. By the same light, its republican potential becomes apparent. For the same reasons that referendums cannot project an uncompounded popular will, equally they cannot be understood as a vehicle of populist tyranny. And while popular power is itself mediated and checked through various procedural mechanisms, the referendum mechanism itself serves, in turn, to check the power of other political organs in the domain of constitutional change. For contemporary republican theorists, state power is non-arbitrary, and therefore consistent with political freedom, to the extent that it is subject to suitable mechanisms of popular contestation and control ${ }^{58}$ ". The "mixed" constitution will contain or at least minimise arbitrary power by providing suitable avenues of contestation. In turn, the constitutional referendum that has so strongly defined Irish constitutional culture can be understood in this light - not as an authorial mechanism through which the people directly exercise constituent power or even "sovereignty", but rather a contestatory mechanism through which representative and executive organs are controlled and held to account ${ }^{59}$.

\section{Ibid.}

55. Pettit, On the People's Terms, op. cit., p. 4-5.

56. Philip Pettit, "Deliberative Democracy, the Discursive Dilemma and Republican Theory", James Fishkin and Peter Laslett (eds), Philosophy, Politics and Society, vol. 7, New York, Cambridge University Press, 2003, p. 138162, p. 140.

57. Ibid.

58. Pettit, On the People's Terms, op. cit.

59. Ibid., Chapter 4. 
Pettit argues that a "plenary" legislative body is too unwieldy and unconstrained to offer an appropriate mechanism of republican government. However, the lack of constraint post-decision is counterbalanced somewhat by the procedural safeguards that operate at the initiation stage - a "plenary" legislature of the people does not offer the open-ended subject-matter discretion that conventional assemblies enjoy. Since the power of initiative is confined to the legislature, this ensures at least a certain degree of contestation and moderation of the referendum proposal itself. More importantly, while the referendum is itself highly constrained, it serves, in turn, to constrain executive and parliamentary power in the domain of constitutional change. In Ireland, this is especially valuable in a context of particularly strong executive dominance. While the constitutional referendum hardly allows the people to originate or author constitutional content, for the reasons outlined, at least it offers a check on the ability of the executive to effectuate constitutional change via the legislative process. And in systems characterised by strong executive dominance over parliament, this assumes critical importance. Under the Irish Free State Constitution (1922-1937), the possibility of amending the constitution via ordinary legislation, rather than referendum, effectively gave the Executive Council a free hand in diluting various constitutional safeguards - for example, removing the provision for popular-initiative referendum, and allowing extensive powers for military tribunals ${ }^{60}$. By way of contrast, the requirement of a constitutional-amendment referendum under the new Constitution of 1937 provided some measure of restraint on the government, despite providing a limited degree of popular empowerment. It helped to ensure a certain degree of constitutional stability compared to the 1922 Constitution, as well as a safeguard against constitutional revisions designed to benefit sitting governments. For example, voters twice rejected attempts to remove the constitutional requirement of PR-STV (proportional representation) for Dáil elections, where this would have benefited the governing Fianna Fáil party ${ }^{61}$. And in addition to the defeated amendments, the referendum requirement has certainly deterred various reforms that Governments would otherwise have pursued through the parliamentary route ${ }^{62}$. Thus although "direct democracy" is often associated with unhinged populism, the constitutional referendum may play an essentially conservative role in entrenching constitutional content. Moreover, it has counterbalanced a general historical tendency that has seen increasing power

60. See Donal Coffey, "Judicial Review in the Irish Free State", Dublin University Law Journal, vol. 33, $\mathrm{n}^{\circ}$ 1, May 2011.

61. Third Amendment of the Constitution Bill 1958; Third Amendment of the Constitution Bill 1968. See also Bill Kissane, "Is the Irish referendum majoritarian?", in Wilfried Marxer (ed.), Direct Democracy and Minorities, London, Springer, 2012, p. 152.

62. In the Irish Free State, ordinary Acts inconsistent with the Constitution were simply accepted by the Courts as amendments to it. See State (Ryan) v Lennon [1935] IR 170. 
accrue to the executive. While failing to provide large-scale popular empowerment, it has facilitated "the diffusion of power across institutions", ${ }^{63}$ thus echoing traditional republican themes.

Of course, constitutional content might be entrenched and stabilised by alternative amendment mechanisms - for example, a parliamentary supermajority but referendums demand a wider, and more public process of contestation and deliberation, in contrast to the party-political bargaining that might secure an enhanced legislative majority. Public justifications will be more widely exchanged. The vast majority of constitutional amendments in Ireland have been supported by a cross-party consensus ${ }^{64}$. But correspondingly, each of these amendments would have mustered a parliamentary super-majority with little public debate.

Relatedly, while the constitutional referendum cannot be understood as giving "direct and unmediated expression [...] to the popular will 65 ", instead it can be valued as a mechanism for promoting popular participation in government. The Irish Constitution has typically been understood as somehow giving voice to an elusive, ephemeral concept of the popular "will" - as implausible as this seems - yet it has rarely been understood as a framework for facilitating participatory and deliberative citizenship, as providing mechanisms through which citizens can participate in the definition of common interests. Yet when re-interpreted in this light, its republican potential becomes more apparent. Of course, compared to traditional republican practices, referendums are relatively undemanding in terms of the scale of civic involvement they demand of citizens (by the same measure they are relatively unintrusive, compared to say, military service.) It may entail relatively superficial, passive engagement. Yet a republican emphasis on participatory constitutional mechanisms may serve as a corrective to the kinds of civic disengagement that may occur in a purely parliamentary system. There is empirical evidence that referendums promote wider participation in politics ${ }^{66}$. Indeed compared to elections, they are more likely to prompt reflection on discrete political issues. Thus, the shift in constitutional discourse witnessed in post-independence Ireland - that is, a shift in emphasis from parliamentary to popular sovereignty - can be interpreted in a distinctly republican light.

63. Kissane, "Is the Irish referendum majoritarian?”, p. 153.

64. Richard Sinnott, "Cleavages, parties and referendums: Relationships between representative and direct democracy in the Republic of Ireland”, European Journal of Political Research, vol. 41, n 6, October 2003, p. 815.

65. O’Cinneide, “The People are the Masters”, p. 260.

66. Smith argued before the House of Lords Select Committee: "by offering the opportunity to participate directly in policy-making, [referendums] made the public more likely to participate in political activity, "as they understand that their participation in the electoral process has real policy implications"; "12 $2^{\text {th }}$ Report", p. 141. See Daniel Smith and Caroline Tolbert, Educated by Initiative: The Effects of Direct Democracy on Citizens and Political Organizations in the American States, Arbor, University of Michigan Press, 2004. 
While many republicans view direct democracy apprehensively, as a source of potential tyranny or domination, I have argued that the constitutional referendum does not in fact constitute "direct democracy" in a meaningful sense. An alternative understanding of the constitutional referendum - assigning the people a contestatory rather than an authorial or constituent role - reconciles it with the historical republican concern for "mixed" government.

\section{Constitutional rights and non-domination}

Many liberal thinkers have understood constitutions as mediating a tension between individual liberal rights, understood as negative rights of non-interference, on the one hand and the democratic value of majority rule on the other. However, republican thinking often rejects or bypasses this kind of conceptual dichotomy. On the one hand, republicans will tend to emphasise the ideal of nonarbitrary government, based on the common good (however defined), rather than the value of majority rule as such: indeed republican thinkers like Madison were notoriously hostile to unbridled or unmediated democracy. Republican thinkers might well (but not necessarily) defend a principle of democracy, not because it enshrines majoritarian will as such, but rather because they believe it promotes either civic virtue or non-domination ${ }^{67}$. Similarly, republicans will typically reject any understanding of individual rights as being purely negative in nature, or as being above and beyond politics. Rather, rights are a part of the "circumstances of politics", and rather than being intrinsically in tension with democratic government, they are constituted and maintained by political activity and by citizenship itself. Thus in the United States, republicans have "challenge[d] a prevailing understanding of the constitution as primarily a set of rules to limit power... and protect individual rights", re-interpreting it instead "as a framework for collective self-government based... on deliberation on common goods ${ }^{68}$. . It has been argued that discourses of "rights" and of human rights in particular, tend to "depoliticise" questions of right, suggesting that rights offer a "boundary around the individual $[. .$.$] defined against the state { }^{69}$, and ignoring the political dimensions of freedom.

Relatedly, republicans generally reject any understanding of freedom as an absence of external restraint on individual choices or actions. Freedom, in the republican sense, does not consist of an absence of interference as such, but rather an absence of domination, where domination is the condition of being subject to

67. Bellamy, Political Constitutionalism.

68. Honohan, Civic Republicanism, p. 7.

69. Duncan Ivison, "Republican Human Rights?", European Journal of Political Theory, vol. 9, n 1, January 2010, p. 34. 
alien will. We can be dominated, Pettit suggests, without ever suffering interference, and conversely, we can suffer interference that is not the manifestation of alien will - and which therefore is not abrogative of freedom at all ${ }^{70}$. Freedom, indeed, has no meaning pre-politically - it can only be realised in a framework of coercive laws. In Rousseau's interpretation of the social contract tradition, we enter into political society not to preserve natural rights that pre-existed political society - but rather to free ourselves of dependency on alien will, which in turn is irreducible to any guaranteed spheres of non-interference for unhindered private actions $^{71}$.

Against this backdrop, Irish constitutional culture seems to be informed by a theory of rights that is decidedly un-republican. While political freedom has been defined in relation to a concept of popular sovereignty as discussed above, individual rights have been defined primarily with reference to a philosophy of natural law. This is partly a product of the Catholic-dominated intellectual climate in which the Constitution originated ${ }^{72}$. This drew, broadly speaking, on Aquinas' understanding of natural law as that part of God's eternal law that is accessible to humans through reason ${ }^{73}$. Clarke describes this as a "hybrid scholastic theory, partly derived from Aquinas and partly inherited from later scholastics through the intermediary of early twentieth-century Roman Catholic theology ${ }^{74}$ ". This theory is particularly evident in the provisions concerning the rights of the family, marriage and property. In the constitutional text itself, rights are described as "natural", "inalienable", "imprescriptible", or "antecedent to positive law" f $^{75}$ ". This philosophy of rights has been further expounded in landmark constitutional judgments. In McGee v Attorney General, Justice Walsh observed:

Articles 41, 42, and 43 emphatically reject the theory that there are no rights without laws, no rights contrary to the law and no rights anterior to the law. They indicate that justice is placed above the law and acknowledge that natural rights or human rights are not created by law but that the Constitution confirms their existence and gives them protection. The individual has natural and human rights over which the State has no authority ${ }^{76}$.

\footnotetext{
70. Pettit, Republicanism, Chapter 2.

71. Jean-Jacques. Rousseau, Du Contrat Social, Paris, ENAG, 1988.

72. Dermot Keogh and Andrew McCarthy, The Making of the 1937 Constitution, Cork, Mercier, 2007.

73. See generally John Finnis, Natural Law and Natural Rights, Oxford, Oxford University Press, 1990.

74. Desmond Clarke, "The Role of Natural Law in Irish Constitutional Law", Irish Jurist, vol. 17, n 1, March 1982, p. 193.

75. See articles 41.1.1, 42.1, 42A.1, 42A.2.1, 43.1.
}

76. McGee v Attorney General [1974] IR 284, 310. 
Thus, natural-law discourse has drawn from secular theories of natural rights as well as the Christian influenced concept that historically predominated. This is particularly evident in the assertion in Article 43.1 that man enjoys the right to property "in virtue of his rational being". This echoes the secular natural-law tradition, influenced especially by the $17^{\text {th }}$-century philosopher John Locke, who argued that governmental authority depends on respect for natural rights that exist before the coming into being of political society ${ }^{77}$.

Justice Walsh suggested that natural rights were not merely "an acknowledgment of the ethical content of law in its ideal of justice ${ }^{78}$ ", but rather, in essence, an integral component of the Constitution and an actionable source of constitutional law. In a bold assertion of judicial power, he went as far as to suggest that it fell to judges, in light of their experience, to determine what such "natural rights" consist of - to "determine, where necessary, the rights which are superior or antecedent to positive law"

However, partly because the content of natural law is notoriously ambiguous ${ }^{80}$, natural-law thinking has done little to settle concrete questions concerning constitutional rights in Ireland. Kavanagh argues that in Ireland, "natural law" simply became a by-word for the idea that judges should strike down those elements of the "positive law" (usually equated with legislation) that contradict an ethical idea of justice. Indeed it does not readily translate to an analytical theory of constitutional rights. Natural law has most often been used to identify "un-enumerated" (implied) constitutional rights - rights such as privacy - which are derived from the overall spirit and ethos of the Constitution. Indeed other, equally vague philosophical concepts such as the "human personality" and the "Christian and democratic nature of the state" have also been invoked ${ }^{81}$. Yet apart from a few cases, natural law has not generally been used to elaborate on the substance of constitutional rights; "judges did not consult the great philosophical texts on natural law, apart from making occasional passing reference to their authors ${ }^{82}$." Indeed, in some cases, natural-law concepts were used not to identify but to limit constitutional rights - for example, in the 1983 Norris case concerning the criminal prohibition of homosexuality ${ }^{83}$.

More broadly, since the 1960s there has been increasing reluctance to use explicitly religious sources for identifying un-enumerated rights - and the citation

77. John Locke, Two Treatises of Government and A Letter Concerning Toleration, Yale, Yale University Press, 2003.

78. McGee v Attorney General [1974] IR 284, 317.

79. [1974] IR 284, 318.

80. John Finnis, Natural Law and Natural Rights, Oxford, Oxford University Press, 1990.

81. Ryan v Attorney General [1965] IR 294; Norris v Attorney General [1984] IR 36.

82. Aileen Kavanagh, "Natural Law, Christian Values and the Ideal of Justice", Irish Jurist, vol. 48, nº 1, 2012, p. 80.

83. [1984] IR 36. 
of papal encyclicals in constitutional-rights cases never survived the processes of secularisation that took root from the $1970 \mathrm{~s}^{84}$. Indeed in the $1972 \mathrm{McGee}$ case, which legalised contraception, Justice Walsh said that constitutional concepts of natural rights were "conditioned by the passage of time ${ }^{85}$ ". More generally, in recent decades there has been growing reluctance to invoke natural-law ideas as a basis for constitutional rights, and a trend towards using more conventionally "legal" sources ${ }^{86}$. Clearly, this trend is inseparable from the broader secularisation of Irish politics and society; however, by the same measure it is unclear what the philosophy of natural rights in the Irish constitution now entails. The Constitution references various secular philosophical concepts - such as the "freedom and dignity" of the individual - but with the decline of natural-law thinking, there is no clear alternative philosophy of constitutional rights. In any event, it seems apparent that rights are still conceptualised not as instruments of the common good or of non-domination, whether social, economic or political - but rather as negative rights that are moral in character and that are defined and understood as being beyond or outside politics, contrary to the dominant republican understanding.

Since freedom, in the republican tradition, consists of non-domination in the sense of non-arbitrary rule - and since domination is based on asymmetric power relationships rather than interference per se - it is arguable, in one sense, that judicially enforced constitutional rights are alien to the republican way of thinking about freedom and rights.

On the one hand, constitutional rights might be thought relatively ineffective in capturing the distributive dimension of freedom understood as non-domination. Freedom, in the republican sense, can be undermined simply by virtue of disparities of power and resources that force some to remain dependent on the goodwill of others. Since non-domination depends on people's "relative powers" - and in particular, the opportunities and resources they enjoy relative to others - it requires a strong commitment to social and distributive justice that probably cannot be captured or realised as a set of individual rights, whether codified constitutionally or otherwise ${ }^{87}$. Republicans will recognise that domination can be constituted by private as well as public power; thus, non-domination requires a much wider political and social project, and not merely safeguards for individuals against encroachments of state power.

Constitutional rights may not only be ineffective, but positively counterproductive in promoting freedom in the republican sense. Republican scholars like 
Richard Bellamy have argued that so-called "legal constitutionalism" - the entrenchment of constitutional principles in legal form - can itself lead to a form of domination by enshrining unaccountable judicial power ${ }^{88}$. Again, this reflects a broader republican scepticism towards the idea that individual freedom is best secured through legal rights that purport to transcend the political and legislative process. Given the disagreement that exists in contemporary societies as to concepts of right, judicial review is an arbitrary method for defining rights, since it is largely immune from the usual channels of accountability and contestation that apply in the political sphere. Given that citizens reasonably disagree as to the scope and meaning of rights and as to the reconciliation of competing rightsclaims, judicially enforced constitutional rights represent a site of unaccountable political power. Many republicans have simply insisted that republican freedom, understood as non-arbitrary rule, lies simply in the political and legislative process through which competing concepts of "rights" are ordered and reconciled, rather than in any definite concept of rights that is put above and beyond political contestation. Any attempt to depoliticise rights, they suggest, is itself a form of political domination. Any attempt to hive off "rights" controversies from the political and legislative process is not only ad hoc and historically specific, but also risks itself constituting a form of arbitrary rule.

However, it is possible to reconceptualise judicially enforced constitutional rights in a manner that is consistent with republican ways of thinking about freedom ${ }^{89}$. In particular, it is possible to understand constitutional rights not as barriers against state power for individuals, but rather as guarantees of non-arbitrary government. Indeed, the republican understanding of freedom as an absence of domination rather than interference - that is, as security against arbitrary power - is arguably echoed, albeit indirectly, in the analytical theory of constitutional rights ${ }^{90}$. Arguably, constitutional-rights jurisprudence, whether in Ireland or elsewhere, does not prohibit interference in protected activities as such, but only arbitrary interference. Generally speaking, interference in protected activity - say, religious practice or political expression - is only impermissible if it is disproportionate to a legitimate public goal connected to the common good ${ }^{91}$. In turn, this is conducive to the historical republican ways of thinking about freedom and "rights". Constitutional rights, in this lens, are not safeguards for individual interests per se, but rather controls on the predicates of public action.

\section{Bellamy, Political Constitutionalism.}

89. For a fuller version of this argument see Eoin Daly, "Freedom as Non-domination in the jurisprudence of constitutional rights", Canadian Journal of Law and Jurisprudence, vol. 28, n 2, July 2015, p. 289-316.

90. Eoin Daly and Tom Hickey, The Political Theory of the Irish Constitution, Manchester, Manchester University Press, 2015, Chapter 2.

91. Heaney v Ireland [1994] 3 IR 593; Cox v Ireland 14 [1992] 2 IR 503. 
For example, articles 8-11 of the European Convention on Human Rights, in requiring that interferences in protected rights are "prescribed by law" (rather than based on administrative discretion), arguably echo a republican concern to prevent arbitrary interference, rather than a "liberal" concern to prevent interference per se. Similarly, the Irish Constitution references similar formulae such as "public order and morality" (Article 44) or "the exigencies of the common good" (Article 43), while constitutional jurisprudence has embraced a proportionality doctrine that developed originally in Canadian and German law ${ }^{92}$. In other instances, constitutional doctrine may account for the republican insight as to those forms of domination that occur without any interference per se ever being suffered, simply by virtue of unchecked power disparities that pertain in public and private spheres ${ }^{93}$. Republicans, to generalise, have understood that citizens may suffer domination where they must live in apprehension of interferences that may occur - even improbably - with a change of circumstance or fortune that renders them vulnerable to the discretion or goodwill of others. While constitutional rights cannot account for the various kinds of power disparities that affect individuals in different social and economic spheres, they can account for the fear or apprehension of interference - the essence of domination - as well as interference that is actually suffered. For example, the Irish Supreme Court has given standing (locus standi) to individuals to challenge laws as unconstitutional, even where they have not suffered actual interference, or where interference is unlikely to occur ${ }^{94}$. The Court has recognised that "the [constitutional] provisions must enable the person invoking them not merely to redress a wrong resulting from an infringement of the guarantees but also to prevent the threatened or impending infringement of the guarantees ${ }^{55}$ "... This is attributable in part to an implicit recognition that constitutional rights may be undermined by the state of uncertainty or fear as to the possibility of future interference in some protected conduct as much as by the actual experience of such interference. Furthermore, it supports the idea that constitutional rights may be understood less as safeguards for unhindered actions for individuals, and more as controls against arbitrary governmental power more generally ${ }^{96}$.

Similarly, constitutional judgments have recognised that violations of rights may occur where criminal offences are defined too vaguely or imprecisely - thus echoing an historical republican concern as to arbitrary power ${ }^{97}$. More generally,

92. Heaney $v$ Ireland [1994] 3 IR 593; Cox v Ireland 14 [1992] 2 IR 503.

93. Daly, "Freedom as non-domination in the jurisprudence of constitutional rights".

94. Norris v Attorney General [1984] IR 36.

95. King v Attorney General [1970] IR 317, 338, emphasis added.

96. See generally Pildes, "Why Rights Are Not Trumps", op. cit.

97. King v Attorney General [1981] IR 233. 
Irish constitutional doctrine has reflected a concern not merely to protect certain zones of individual activity, but rather to check the means and process through which activities are hindered or restricted. It has been recognised, for example, that restrictions on constitutional rights must be grounded in legislation rather than official discretion ${ }^{98}$. This echoes provisions of the European Convention of Human Rights which provide that restrictions on the liberties of expression and of thought, conscience and belief must be exercised "in accordance with law ${ }^{99 "}$. The concern is not to guarantee non-interference per se in relation to particular activities, but rather to protect against discretion, which is understood by republicans, historically, as the essence of arbitrary power ${ }^{100}$. And while some degree of discretion is inevitable in the modern administrative state, Irish constitutional doctrine has aimed to curtail its potentially arbitrary character in insisting, in particular, that officials vested with discretionary powers are obliged to give those affected by their decisions an opportunity to be heard and to put their case (audi alteram partem), to refrain from taking irrelevant considerations into account, to provide reasons for their decisions, and to avoid any perception of bias or partiality ${ }^{101}$. Again, more generally, these examples illustrate that the focus of constitutional doctrine is not necessarily "liberal", as widely assumed, but at least potentially republican - because its concern is not to guarantee non-interference for individuals as such but rather to ensure the non-arbitrariness of governmental power.

\section{橉 Conclusion}

The Irish Constitution has not traditionally been understood and discussed using a specifically republican discourse, of the kind that prevails in other constitutional cultures such as that of France, or perhaps the United States. Instead, Irish constitutional culture has been informed either by rather generic, almost platitudinous doctrines such as that of popular sovereignty - or an elusive notion of rule by the popular "will" - or, indeed, by distinctly un-republican concepts such as Christian values and natural law. While the democratic doctrine of the Constitution seems politically naïve, the philosophy of natural law has not meaningfully survived the processes of secularisation that Ireland has undergone since independence. As a result, contemporary Irish constitutional culture lacks a definite

98. See DPP v Fagan [1994] 2 IR 265; Howard v Commisioners of Public Works [1994] 1 IR 101. Articulating a more general principle of legality, Justice Kearns stated: "every executive or administrative act which affects legal rights, interests or legitimate expectations must be legally justified.” Browne v Attorney General [2002] IEHC 47.

99. See Articles 8-10, European Convention on Human Rights.

100. Timothy O’Neill, “Liberal Constitutionalism \& Bureaucratic Discretion”, Polity, vol. 20, nº 3, Spring 1988. 101. McDonald v Bord na gCon [1965] IR 217. 
philosophical identity. I have not argued that historically, the 1937 Bunreacht can be understood as a quintessentially or authentically "republican" charter. However, I have argued that despite the absence of a republican discourse in Irish constitutional culture, its existing devices and institutions can be reconceptualised in a republican light, or at least in a manner that is consistent with republican ways of thinking about political freedom and individual rights. In turn, the Constitution provides a fruitful avenue for republican thinking in the context of a revived interest in civic-republican thought in contemporary Ireland. 